\title{
ZNAČAJ NACIONALNOG PARKA SJEVERNI VELEBIT U ZAŠTITI PRIRODE S OBZIROM NA GLJIVE
}

\author{
Neven Matočec \\ Ivana Kušan \\ Institut Ruđer Bošković \\ Bijenička cesta 54 \\ HR 10000 Zagreb \\ nmatocec@irb.hr \\ ikusan@irb.hr \\ Dušan Mrvoš \\ Ulica grada Vukovara 224 \\ HR 10000 Zagreb \\ dusan.mrvos@gmail.com
}

UDK: 502:581.9(234Velebit)

Pregledni članak

7.10.2019.

\begin{abstract}
Područje Nacionalnog parka Sjeverni Velebit odlikuje visoka raznolikost gljiva. Do danas je u Parku zabilježeno oko 750 vrsta gljiva, od kojih je 20 strogo zaštićeno. Novija istraživanja rezultirala su opisivanjem jednog roda te čak pet novih vrsta gljiva za znanost. U ovome radu posebno se obrađuju gljivlje vrste visokih bioindikatorskih vrijednosti za kvalitetu sustava zaštite prirode, predstavljene u tri skupine: (1) vrste biotrofno vezane za endemske vrste - endemobionti/endemofili, (2) ekološki stenovalentne vrste vezane na izmete životinja te (3) ekološki stenovalentne vrste vezane za stare šume i prašume. Sve su tri grupe pod snažnim utjecajem lokalno-specifičnih klimatskih karakteristika. Prema analiziranim podacima može se reći da je NP Sjeverni Velebit vrlo uspješno dizajniran s obzirom na zaštitu gljiva. Zbog svoje raznolikosti i specifičnosti, NP Sjeverni Velebit može se označiti kao Područje važno za gljive - Important Fungus Area (IFA).
\end{abstract}

Ključne riječi: endemobiont, endemofil, ekologija gljiva, IFA, zaštita gljiva

\section{Uvod}

Nacionalni park Sjeverni Velebit (NPSV) utemeljen je 1999. godine i najmlađi je Nacionalni park u Republici Hrvatskoj ${ }^{1}$. Cijelo područje Parka, zajedno s Parkom prirode Velebit te Nacionalnim parkom Paklenica

${ }^{1}$ www.np-sjeverni-velebit.hr. 
uključeno je u ekološku mrežu Europske unije NATURA 2000 donošenjem Uredbe o ekološkoj mreži ${ }^{2}$, a znatno je ranije (1978.) UNESCO čitavu planinu Velebit proglasio Svjetskim rezervatom biosfere, što je uskoro rezultiralo proglašenjem cijele planine Parkom prirode.

Prema direktivama NATURA 2000, NPSV je područje očuvanja značajno za 12 vrsta i 13 stanišnih tipova, a nalazi se i unutar područja očuvanja značajnog za ptice ${ }^{3}$. Na razmjerno maloj površini Parka $\left(109 \mathrm{~km}^{2}\right)$ nalaze se vrlo raznolika, visoko geospecifična i mozaički raspoređena staništa prepuštena prirodnom razvoju ili djelomično izložena tradicionalnom gospodarenju. Ta su mnogobrojna staništa zgusnuta na vrlo malom prostoru, ali zahvaljujući posebnom geografskom položaju i reljefu zahvaćaju subalpski (vršna zona), altimontani (kontinentalna strana) te submediteranski i montano-mediteranski bioklimatski pojas (primorska strana). Velika raznolikost staništa preduvjet je i visoke bioraznolikosti gljiva koje u svim tim staništima čine ekološki iznimno značajnu skupinu organizama. Određeni tipovi staništa koji čine ekološki i krajobrazno vrijedan i značajan dio NPSV-a iznimno su vrijedni s obzirom na gljive. Mnoga od ovih staništa ugrožena su na razini cijele Hrvatske, ali i u Europi. To se prije svega odnosi na stare šume i prašume (smreke, bukve, crnog bora te jele i smreke), jame ledenice u dnima dubokih ponikava na vršnim područjima, malobrojne travnjake održavane pokretnim (transhumantnim) stočarenjem te prirodne obalne zone slatkovodnih staništa (potoka i lokvi) u neposrednom okruženju šuma veće starosti. Određeni broj užih lokaliteta s navedenim tipovima staništa od najveće važnosti za nacionalnu, ali i svjetsku bioraznolikost, sustav zaštite prirode već je prepoznao i prije osnutka NPSV-a proglašavajući strogim prirodnim rezervatom Hajdučke i Rožanske kukove, a područja Visibabe i Zavižan - Balinovac - Velika kosa posebnim botaničkim rezervatima. Tek se osnivanjem NPSV-a koji objedinjuje sve te vrijedne prirodnine osigurala stabilnost i sigurnost zaštite tih područja, ali su se zaštitom učinkovito obuhvatili i time od neposredne degradacije osigurali i oni tipovi staništa koji su prethodno bili unutar Parka prirode bez posebnog zaštitnog statusa. U mikološkom pogledu, to su prije svega stare sastojine crnoga bora, stare šume četinjača boreo-montanog tipa, stalne tekućice s prirodnom obalnom zonom i altimontani travnjaci nastali pokretnim stočarenjem (transhumancom).

\footnotetext{
${ }^{2}$ Narodne novine, 124, 2013.

${ }^{3}$ JU NP Sjeverni Velebit, 2017.
} 
Povijest mikoloških istraživanja na području Nacionalnog parka Sjeverni Velebit

Prvi podaci o gljivama s područja današnjeg NPSV-a datiraju iz prve polovice 20. stoljeća kada je prve nalaze lišaja (liheniziranih gljiva) objavio češki lihenolog Miroslav Servít ${ }^{4}$. Servít je najviše istraživao područje oko Mirova, Alana i Štirovače. Fitopatolog Vladimir Škorić je u svome radu o parazitskim gljivama $^{5}$ objavio nekoliko vrsta gljiva s područja planine Velebit, ali bez preciznijeg navođenja lokaliteta tako da ostaje nepoznato je li istraživao područje sadašnjeg NPSV-a. Adolf H. Magnusson autor je monografije liheniziranog roda Ionaspis ${ }^{6}$ u kojoj je obrađeno nekoliko uzoraka s područja Mirova. Mađarski botaničar Árpad von Degen je u svom opsežnom djelu "Flora Velebitica" jedno poglavlje posvetio lišajima ${ }^{7}$, dok je $u$ istom djelu prve nelihenizirane gljive na području današnjeg NPSV-a zabilježio Gusztáv Moesz ${ }^{8}$. Sredinom 20. stoljeća sve do tada objavljene podatke o lišajima s područja Velebita, uključujući i Sjeverni Velebit, sintetizirao je hrvatski lihenolog i botaničar Fran Kušan u svojem sveobuhvatnom djelu Prodromus lišaja Jugoslavije9. Mikološka istraživanja ovog područja nastavljena su u drugoj polovici 20. stoljeća kada je gljive Velebita istraživala hrvatska mikologinja Milica Tortić ${ }^{10}$. U svome posljednjem radu o velebitskim gljivama autorica je dala pregledni popis svih do tada zabilježenih neliheniziranih makrogljiva (vrsta gljiva s makroskopskim plodištima) planine Velebit i okolnih krajeva. Istraživanja lišaja na području NPSV-a su također nastavljena i u drugoj polovici 20. stoljeća kada su danski lihenolozi Steen N. Christensen ${ }^{11}$ te Steen N. Christensen i Eric S. Hansen ${ }^{12}$ objavili nalaze vrsta iz područja sjeverno od vrha Vučjak (1644 m). U sklopu svojih istraživanja fitopatogenih gljiva na samoniklim biljkama Hrvatske (2007. - 2012.), nalaze s područja NPSV-a objavili su Tihomir Miličević i suradnici ${ }^{13}$.

Prva sustavna istraživanja bioraznolikosti neliheniziranih gljiva iz odjeljaka Basidiomycota (bazidiomiceti) i Ascomycota (askomiceti) na području NPSV-a

${ }^{4}$ M. SERVÍT, 1929, 1-38; M. SERVÍT, 1931, 215-282, M. SERVÍT, 1934, 119-160; M. SERVÍT, 1939; 113-168.

${ }^{5}$ V. S̆KORIĆ, 1928, 97-108.

${ }^{6}$ A. H. MAGNUSSON, 1933, 1-47.

${ }^{7}$ A. von DEGEN, 1938, 299-379.

${ }^{8}$ G. MOESZ, 1938, 281-298.

${ }^{9}$ F. KUŠAN, 1953.

${ }^{10}$ M. TORTIĆ, 1980a, 145-151; M. TORTIĆ, 1980b, 15-25; M. TORTIĆ, 1993, 81-96.

${ }^{11}$ S. N. CHRISTENSEN, 1987, 161-171.

${ }^{12}$ S. N. CHRISTENSEN - E. S. HANSEN, 1994, 101-113.

${ }^{13}$ T. MILIČEVIĆ et al., 2014, 179-187. 
započeli su mikolozi Zdenko Tkalčec, Armin Mešić, Neven Matočec i Ivana Kušan 2003. g., a djelomično se ta istraživanja provode još i danas. U posljednje vrijeme ovi istraživači objavili su znanosti do tada nepoznate, nove vrste ${ }^{14}$, dok su I. Kušan i N. Matoče ${ }^{15}$ izradili i Program monitoringa gljiva travnjaka NPSV-a u sklopu Projekta uvođenja ispaše na travnjak Lubenovac unutar NPSV-a.

Nacionalni park $u$ sustavu zaštite prirode $i$ značajni elementi njegove mikobiote

Gljive imaju ključnu ulogu u kruženju tvari i energije u svim kopnenim ekosustavima i bez njih život na Zemlji kakvog znamo ne bi bio moguć. Kao saprotrofi (saprobionti) razgrađuju mrtvu organsku tvar, kao paraziti hrane se organskim tvarima iz tijela živih organizama, a kao mutualisti ulaze u mikorizni odnos s korijenovim sustavom biljaka ili pak u zajednicu s algama ili cijanobakterijama tvoreći lišaje. Iznimno je značajna uloga gljiva u odvijanju ekoloških procesa u kopnenim ekosustavima, posebno u šumskima. Dok životinjske ostatke većinom razgrađuju bakterije, u razgradnji biljnih ostataka dominiraju gljive. Razgradnja lignina isključivo je zadaća gljiva pa je njihova uloga u razgradnji mrtvih drvnih ostataka nezamjenjiva.

Prema Crvenoj knjizi gljiva Hrvatske ${ }^{16}$, glavni uzroci ugroženosti gljivljih vrsta u Hrvatskoj su nestajanje, degradacija ili fragmentacija staništa, onečišćenje, klimatske promjene te neodgovarajuće i prekomjerno skupljanje plodišta za hranu. Značaj zaštićenih područja, poput nacionalnih parkova, je izniman jer na tim područjima ugroženi organizmi uživaju zaštitu u smislu maksimalnog očuvanja njihovih staništa te zabrane sakupljanja za hranu.

Recentna istraživanja znatno su doprinijela spoznaji o raznolikosti neliheniziranih gljiva na području Parka. Uzevši u obzir omjer 6:1 između broja vrsta gljiva i biljaka na nekom području koji se koristi za najkonzervativnije procjene broja vrsta gljiva koje žive na nekom području ${ }^{17}$, pretpostavljeni broj vrsta gljiva u NPSV-u bio bi oko 5.500 vrsta. Ova procjena temelji se na 925 vrsta i podvrsta biljaka koliko je do sada zabilježeno u Parku ${ }^{18}$. Ukupan broj do danas poznatih vrsta gljiva, uključujući i lišaje, u Parku iznosi oko 750. Pregled

${ }^{14}$ I. KUŠAN et al., 2015, 51-63; I. KUŠAN et al., 2018, 15-47; P. CROUS et al., 2017, 625-715; P. CROUS et al., 2019, 291-473; R. PHOOKAMSAK et al., 2019, 1-273.

${ }^{15}$ I. KUŠAN - N. MATOČEC, 2018.

${ }^{16}$ Z. TKALČEC et al., 2008.

${ }^{17}$ D. L. HAWKSWORTH, 1991, 641-655.

${ }^{18}$ J. RADOVIĆ, 2007. 
svih do tada poznatih vrsta gljiva iz reda Agaricales s.l. (uključujući redove Boletales i Russulales) za područje NPSV-a objavili su Tkalčec i suradnici ${ }^{19}$. Autori su utvrdili 98 vrsta iz reda Agaricales s.l. od čega je čak 87 vrsta po prvi puta pronađeno u Parku. Prema Crvenoj knjizi gljiva Hrvatske ${ }^{20}$ na području Parka živi 14 strogo zaštićenih vrsta gljiva ${ }^{21}$, a kasnijim istraživanjima ${ }^{22}$ broj poznatih strogo zaštićenih vrsta povećan je za šest (Tablica 1). Više desetaka vrsta, npr. iz rodova Chlorencoelia, Chloroscypha, Entoloma, Kuehneromyces, Lasiobelonium, Mollisia, Otidea, Peziza, Pirottaea, Psathyrella, Pseudoomphalina, Psilocybe, te Vibrissea, zabilježeni su do sada u Hrvatskoj samo na području ovog Parka.

Tabl. 1. Strogo zaštićene vrste gljiva zabilježene u Nacionalnom parku Sjeverni Velebit.

\begin{tabular}{|c|c|c|}
\hline Ime vrste & $\begin{array}{c}\text { IUCN } \\
\text { kategorija } \\
\text { ugroženosti }\end{array}$ & Referenca \\
\hline promjenjivi dlakojezičnjak (Trichoglossum variabile) & $\mathrm{CR}$ & I. KUŠAN et al., 2016. \\
\hline crvenkasta jodokorka (Amylocorticium subincarnatum) & EN & Z. TKALČEC et al., 2008. \\
\hline planinska rudoliska (Entoloma catalaunicum) & $\mathrm{EN}$ & Z. TKALČEC et al., 2008. \\
\hline borova bodljočaška (Desmazierella acicola) & EN & I. KUŠAN et al., 2016. \\
\hline planinska rudočaška (Rhodoscypha ovilla) & $\mathrm{EN}$ & I. KUŠAN et al., 2016. \\
\hline sjajna pozelenka (Caloscypha fulgens) & VU & Z. TKALČEC et al., 2008. \\
\hline okruglasta kožoglavka (Cudonia circinans) & VU & Z. TKALČEC et al., 2008. \\
\hline planinska pločarica (Discina montana) & VU & Z. TKALČEC et al., 2008. \\
\hline dvobojni hrčak (Helvella albella) & VU & Z. TKALČEC et al., 2008. \\
\hline kasna puževica (Hygrophorus hypothejus) & VU & Z. TKALČEC et al., 2008. \\
\hline kapljičasta ljepljivica (Limacella guttata) & VU & Z. TKALČEC et al., 2008. \\
\hline krhkonoga pritajnica (Marasmius collinus) & VU & Z. TKALČEC et al., 2008. \\
\hline prašumska planinka (Tatraea dumbirensis) & VU & Z. TKALČEC et al., 2008. \\
\hline blijedožuta pločarica (Discina leucoxantha) & VU & I. KUŠAN et al., 2016. \\
\hline listićavi hrčak (Helvella phlebophora) & VU & I. KUŠAN et al., 2016. \\
\hline gorka plamenka (Gymnopilus picreus) & DD & Z. TKALČEC et al., 2008. \\
\hline proljetna panjevčica (Kuehneromyces lignicola) & $\mathrm{DD}$ & Z. TKALČEC et al., 2008. \\
\hline $\begin{array}{l}\text { stisnutonoga lažnoljevčica (Pseudoomphalina } \\
\text { kalchbrenneri) }\end{array}$ & DD & Z. TKALČEC et al., 2008. \\
\hline polukuglasta strnišnica (Stropharia semiglobata) & $\mathrm{DD}$ & Z. TKALČEC et al., 2008. \\
\hline konjska strnišnica (Stropharia dorsipora) & $\mathrm{DD}$ & I. KUŠAN et al., 2015. \\
\hline
\end{tabular}

${ }^{19}$ Z. TKALČEC et al., 2005a, 341-349.

${ }^{20}$ Z. TKALČEC et al., 2008.

${ }^{21}$ NARODNE NOVINE, 144/2013.

${ }^{22}$ I. KUŠAN et al., 2015, 51-63; I. KUŠAN et al., 2016. 


\section{Gljive odjeljka Ascomycota u Nacionalnom parku Sjeverni Velebit}

Izuzetno velika raznolikost i specifičnost staništa koja su mozaički raspoređena na vrlo malom prostoru unutar granica samog NPSV-a zahtijeva dugotrajno istraživanje kako bi se mogao sagledati značajan udio ukupne postojeće bioraznolikosti gljiva. Tako su terenska istraživanja gljiva iz odjeljka Ascomycota u različitim staništima i u različitim sezonama (proljeće, ljeto, jesen) rezultirala visokim udjelom novozabilježenih vrsta gljiva (za područje samog Parka i za područje Hrvatske) svake godine tijekom desetogodišnjeg razdoblja $^{23}$ (Sl. 1). Ova činjenica ne iznenađuje jer je raznolikost gljiva na ovome području zasigurno znatno veća od one trenutno poznate i nakon 12 godina istraživanja (autori ovog rada su do 2019. utvrdili 390 vrsta iz odjeljka Ascomycota). U daljnjoj razradi problematike koncentrirat ćemo se upravo na gljive iz odjeljka Ascomycota. Od 12-ak danas priznatih odjeljaka carstva gljiva, odjeljku Ascomycota pripada oko 2/3 svih vrsta gljiva. Gljive iz ove skupine prisutne su u svim tipovima staništa, a u nekima čak i dominiraju biomasom (tundre) ili čine golemu većinu gljivlje bioraznolikosti (slatkovodna i morska staništa). Praktički u svim tipovima staništa, brojni pripadnici askomiceta vrijedne su indikatorske vrste ${ }^{24}$. Od vrijednih bioindikatora u NPSV-u, osim brojnih vrsta liheniziranih gljiva čija je sposobnost ukazivanja na kvalitetu zraka već odavno poznata ${ }^{25}$, utvrđene su i brojne indikatorske vrste prašumskih staništa (npr. prašumska planinka - Tatraea dumbirensis ${ }^{26}$, okruglasta

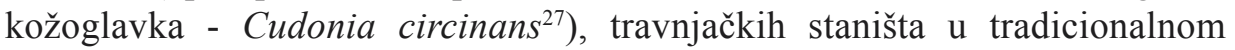
gospodarenju (npr. velebitska bubnjarica - Thecotheus platyapiculatus ${ }^{28}$, promjenjivi dlakojezičnjak - Trichoglossum variabile ${ }^{29}$ ) i drugih tipova staništa. Istraživanja bioraznolikosti gljiva odjeljka Ascomycota na području Parka u posljednje vrijeme rezultirala su i objavom novih vrsta za znanost, koje do tada nisu bile poznate. To su: velebitska bubnjarica - Thecotheus platyapiculatus I. Kušan \& Matočec ${ }^{30}$, (u istom radu objavljen je i pregled dodatnih 19 do tada neobjavljenih fimikolnih vrsta gljiva koje su zabilježene na području NPSV-a), velebitska svjetlorupka - Pyrenopeziza velebitica Matočec, I. Kušan, Jadan.,

${ }^{23}$ I. KUŠAN et al., 2017.

${ }^{24}$ N. JUKIĆ et al., 2019.

${ }^{25}$ B. W. FERRY et al., 1973.

${ }^{26}$ H.-O. BARAL et al., 1999, 71-82.

${ }^{27}$ Z. TKALČEC et al., 2008.

${ }^{28}$ I. KUŠAN et al., 2015, 51-63.

${ }^{29}$ Z. TKALČEC et al., 2008.

${ }^{30}$ I. KUŠAN et al., 2015, 51-63. 


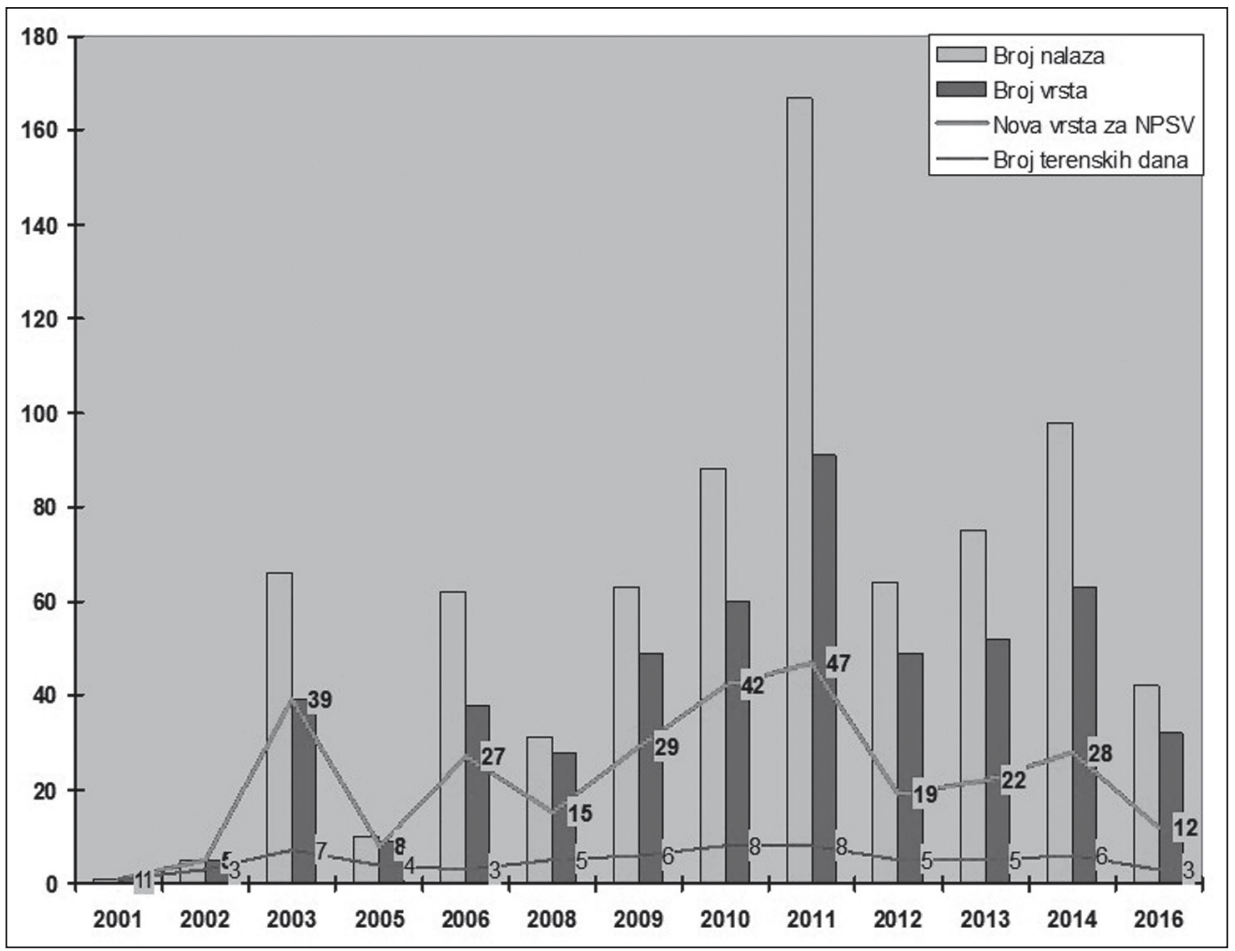

Sl. 1. Dinamika istraživanja gljiva iz odjeljka Ascomycota na području Nacionalnog parka Sjeverni Velebit (2001. - 2016.) (izradila: Ivana Kušan)

Tkalčec et Mešić ${ }^{31}$, divokozin gumbić - Coprotus epithecioides Matočec \& I. Kušan ${ }^{32}$, te smrekina pločica - Mollisia endocrystallina Matočec, I. Kušan, Jadan, Mešić \& Tkalčec ${ }^{33}$ ), ali i jednog za znanost novog roda (i vrste), žutomesna velebitka - Velebitea chrysotexta I. Kušan, Matočec \& Jadan ${ }^{34}$, koji je ime dobio u čast planine Velebit.

Kao poseban dio razmatranja značaja NPSV-a na deskriptivnoj razini, izdvojeno je sedam vrsta iz odjeljka Ascomycota koji prema svojim različitim, vrlo specijaliziranim životnim strategijama, imaju posebne indikatorske vrijednosti za kvalitetu sustava zaštite prirode te predstavljaju čvrste razloge

\footnotetext{
${ }^{31}$ P. CROUS et al., 2017, 270-467.

${ }^{32}$ I. KUŠAN et al., 2018, 15-47.

${ }^{33}$ P. CROUS et al., 2019, 291-473.

${ }^{34}$ R. PHOOKAMSAK et al., 2019, 1-273.
} 
za njihovu zaštitu. Te vrste posebno su detaljno ekološki karakterizirane s obzirom na njihov teleomorfni (spolni) stadij. Dio se gljivljih vrsta u prirodi razmjerno redovito pojavljuje u tom stadiju za koji je značajna genetička rekombinacija. Kako gljivlji organizam za tvorbu anamorfnog (nespolnog) stadija treba znatno manje energije ${ }^{35}$, vrlo veliki broj askomiceta se češće javlja u tom stadiju, a mnoge su vrste do danas poznate samo u tom obliku (spolni stadij je nepoznat ili čak možda evolucijski izgubljen) jer se te gljive vrlo uspješno mogu rasprostranjivati mitotski nastalim propagulama (konidijama) i pod vrlo nepovoljnim uvjetima ${ }^{36}$. Ipak, u ovome radu pridana je posebna pažnja gljivama u teleomorfnom stanju jer ono indicira specifične, pogodne uvjete pod kojima se gljivlji organizam može rasprostranjivati genetički rekombiniranim propagulama (askosporama) što je evolucijski povoljnije od dugotrajnog repliciranja postojeće genetičke strukture.

\section{(1) Vrste biotrofno usko vezane za endemske vrste}

Ovoj grupi pripadaju vrste koje dugo vremena iskorištavaju sadržaj živih stanica $\mathrm{i} /$ ili njihovih produkata, ne ubijajući svoga domaćina, a često omogućuju jedinki na kojoj žive odvijanje čitavog životnog ciklusa. Kada su takve vrste ograničene na vrstu domaćina koji je endem, tada se i gljivlje vrste koje na njima žive mogu smatrati endemskim vrstama ${ }^{37}$. Ovakav odnos između endemskih organizama i visokospecijaliziranih gljiva koje na njima žive predstavljaju specifičan razlog (potencijalne) ugroženosti i specifičan razlog za zakonsku zaštitu.

\section{Pyrenopeziza velebitica Matočec, $I$. Kušan et al.}

Teleomorfni stadij (apotecijalna plodišta) ove vrste razvija se na kori i oštećenim dijelovima grančica endemske borbaševe kozokrvine (Lonicera borbasiana) ${ }^{38}$ (Sl. 2b, d). Grančice na kojima se ova vrsta može pronaći tijekom proljeća, nisu odumrle, nego su dio žive biljke (Sl. 2c). Plodišta se redovito nalaze na živim biljkama sa zelenim listovima, a neke i na onima koje cvatu (Sl. 2c)! Stoga se može zaključiti kako jedinke borbaševe kozokrvine mogu proživjeti s fruktifikacijama ove gljive kroz cijelu vegetacijsku sezonu jer su promatrane

\footnotetext{
${ }^{35} \mathrm{~N}$. MATOČEC, 2002.

${ }^{36}$ N. MATOČEC et al., 2014.

${ }^{37}$ N. MATOČEC, 2002.

${ }^{38}$ P. CROUS et al., 2017, 270-467.
} 


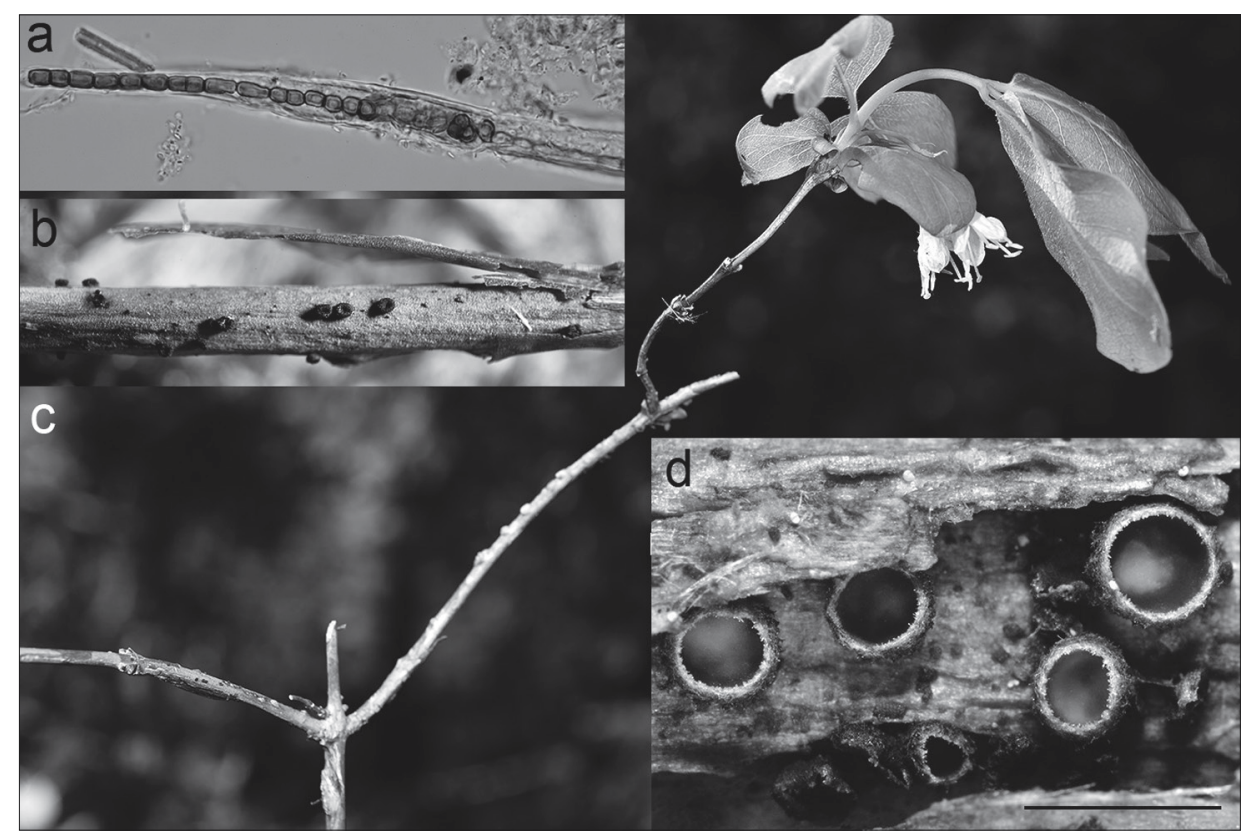

S1. 2. Velebitska svjetlorupka (Pyrenopeziza velebitica) na borbaševoj kozokrvini (Lonicera borbasiana): a) Niz tamnih kuboidnih stanica gljive unutar traheje biljnog domaćina; b) i c) položaj plodišta gljive na živoj biljci u cvatu; d) plodišta gljive (apoteciji). Mjerila: $\mathrm{a}=10 \mu \mathrm{m}, \mathrm{b}, \mathrm{d}=1 \mathrm{~mm}$. (Foto: N. Matočec i I. Kušan)

biljke pronađene žive i u jesen. Da je $P$. velebitica biotrofno vezana na svog domaćina, potvrđuju analize presjeka kroz supstrat neposredno ispod mjesta iz kojih su se razvili apoteciji. Agregacije smeđestjenih stanica koje se razvijaju subepidermalno, u direktnoj su vezi sa subikularnim hifama u bazi svakog plodišta, a u trahejama se često mogu pronaći nizovi kuboidnih stanica (S1. 2a). Ova se vrsta gotovo sigurno prenosi na druge jedinke domaćina putem askospora koje se aktivno izbacuju iz sporangija (askusa) pomoću turgora i bivaju raznošene zračnim strujama. Osim na Hajdučkim kukovima ova je vrsta zabilježena još i na Rožanskim kukovima, no s obzirom na očitu specijalizaciju ove gljive na borbaševu kozokrvinu, mogla bi se očekivati i na drugim područjima Dinarida gdje je rasprostranjena ova biljna vrsta. U dosadašnjim ciljanim istraživanjima drugih vrsta kozokrvina, nije pronađena ova vrsta gljive. 
Rhachomyces hypogaeus (Thaxt.) Thaxt.

Novija istraživanja ${ }^{39}$ su pokazala kako su svi navodi nalaza vrste $R$. hypogaeus s područja Pireneja, kao i nalazi s kornjaša iz rodova Aphaenops i Geotrechus pogrešni te da oni pripadaju vrsti $R$. aphaenopsis. Nalaz na kornjašu Speotrechus mayeti iz južne Francuske danas predstavlja zasebnu vrstu $R$. richardii. Zato se može zaključiti da je areal vrste $R$. hypogaeus ograničen na sjeverozapadne i središnje Dinaride i kornjaše iz roda Typhlotrechus. $\mathrm{Na}$ temelju dosadašnjih istraživanja vidljivo je kako su troglobiontne vrste, koje su se pod posebnim ekološkim pritiscima potpuno prilagodile životu u špiljskim uvjetima ${ }^{40}$, znatno više specijalizirane za određene domadare od svojih srodnika koji mogu živjeti izvan špilja, kao što su $R$. canariensis i $R$. stipitatus. Iz istog razloga, sve troglobiontne vrste roda Rhachomyces su više ili manje stenoendemi, zajedno sa svojim troglobiontnim kornjašimadomadarima. Osim stroge ograničenosti na endemske špiljske kornjaše, $R$. hypogaeus dijeli i opći razlog ugroženosti s drugim špiljskim živim bićima zbog visokog stupnja ugroženosti špiljskih staništa ${ }^{41}$. Prema Huldénu ${ }^{42}$ ove mikroskopski sitne gljive koje žive na hitinskom egzoskeletu člankonožaca (Sl. 3) svojim domaćinima nanose vrlo malu ili nikakvu štetu, što ovisi o intenzitetu i položaju infestacije, pa se $R$. hypogaeus može smatrati više komenzalom nego parazitom. Gotovo sigurno se prenosi bliskim kontaktima među jedinkama iste vrste, a za NPSV je utvrđena nedavnim uključenjem špiljskih staništa u okvir istraživanja askomiceta ${ }^{43}$.

(2) Vrste usko povezane s izmetima životinja i lokalno-specifičnim klimatskim karakteristikama

Obligatno fimikolne (koprofilne) gljive izuzetno su važne u kruženju tvari u prirodi budući da sudjeluju u razgradnji biljnih ostataka koji neprobavljeni prolaze kroz probavu preživača. Vrste koje su u velikoj mjeri ili u potpunosti prilagođene razlaganju tvari u izmetu preživača gotovo u potpunosti ovise o očuvanju antropogenih travnjaka i tradicionalnog stočarenja na njima ${ }^{44}$. U

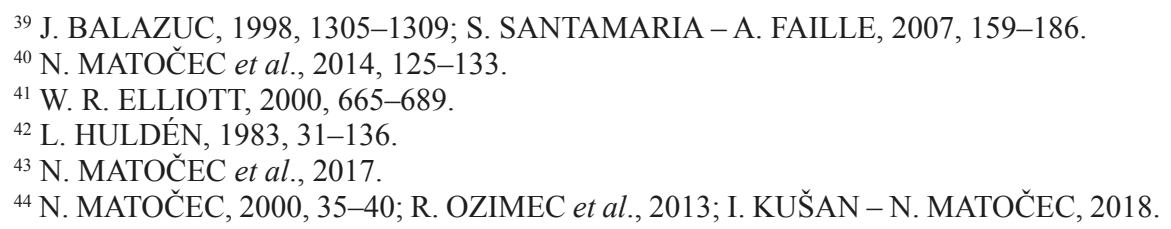



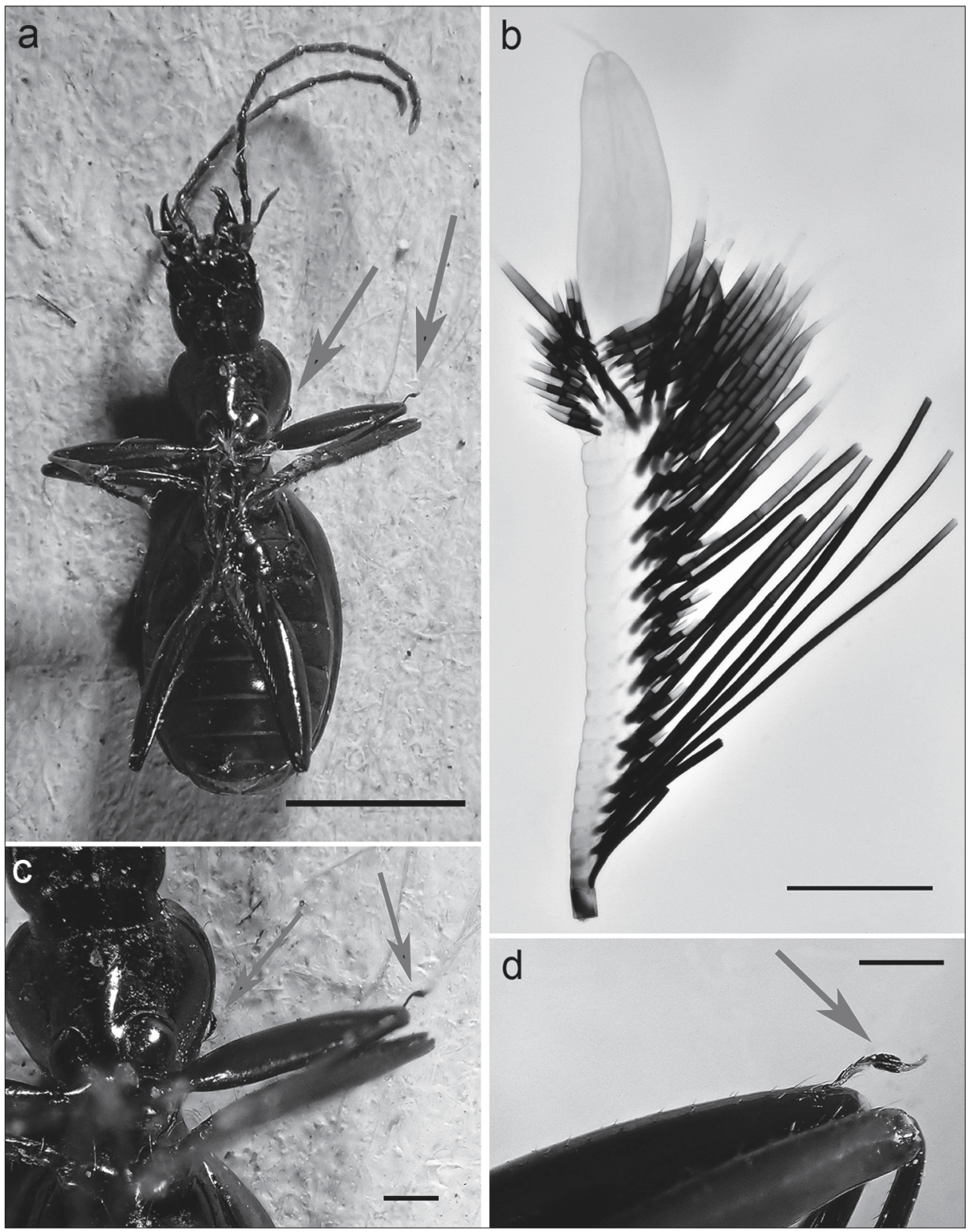

S1. 3. Gljiva špiljska klasnica (Rhachomyces hypogaeus) na kornjašu Typhlotrechus bilimeki. a), c), d) raspored jedinki gljive na egzoskeletu kukca; b) mikroskopski prikaz jedinke gljive. Mjerilo: $\mathrm{a}=5 \mathrm{~mm}, \mathrm{~b}=100 \mu \mathrm{m}, \mathrm{c}=1 \mathrm{~mm}, \mathrm{~d}=0.5 \mathrm{~mm}$. (Foto: N. Matočec i I. Kušan) 
ovim slučajevima zaštita pojedinih divljih životinjskih vrsta, pasmina domaćih životinja te aktivne mjere očuvanja tradicionalnog stočarenja u direktnoj su vezi i sa zaštitom te očuvanjem specijaliziranih gljiva koje čine značajan dio lokalne, nacionalne, ali i svjetske bioraznolikosti.

\section{Coprotus epithecioides Matočec \& I. Kušan}

Vrsta Coprotus epithecioides pronađena je na izmetu divokoze na području Hajdučkih kukova ${ }^{45}$ na kojem je pronađen njezin teleomorf (apotecijalna plodišta) (Sl. 4a). Ovaj lokalitet je trenutno i jedino poznato nalazište ove vrste u svijetu pa je vrsta ne samo obligatni fimikolni organizam već je moguće da ima usku ekološku preferenciju na poseban tip klime i tip supstrata. Ova vrsta vjerojatno ne bi bila pronađena na području Parka da na tom prostoru nema adekvatne zaštite velikih divljih životinja (u ovom slučaju populacija divokoze). Dosadašnja vrlo brojna i detaljna istraživanja fimikolnih gljiva na izmetima domaćih životinja u velikom broju država nisu rezultirala nalazom ove vrste.

Thecotheus platyapiculatus I. Kušan \& Matočec

U okviru razvoja svoje spolne faze (teleomorfa), T. platyapiculatus je obligatno fimikolna vrsta koja živi kao saprotrof izmeta konja (Sl. 4b, c) i do sada je u Hrvatskoj zabilježena samo na jednom lokalitetu unutar NPSV-a, na zavižanskom području, odakle je i opisana kao nova vrsta za znanost ${ }^{46}$. Na prostranim planinskim travnjacima toga područja, na oko $1500 \mathrm{~m}$ nadmorske visine gdje se provodi stalna ispaša konja, vladaju rigorozni klimatski uvjeti. Zime su dugotrajne i oštre s vrlo kratkim trajanjem prosječne dnevne osunčanosti, ukupna godišnja količina oborina (posebno oborine od magle) vrlo je velika, ukupno trajanje naoblake i magle izuzetno je dugotrajno, dok tijekom kraćeg ljetnog razdoblja često nastupaju uvjeti jake suše (posebno imajući u vidu kršku površinsku bezvodnost), mraz i magla su mogući cijele godine, a cijelo područje izloženo je snažnim naletima bure ${ }^{47}$. Ova vrsta vjerojatno ne bi bila pronađena na području Parka da na tom prostoru nema adekvatne zaštite održavanja tradicionalnog stočarstva (konji na slobodnoj ispaši).

\footnotetext{
${ }^{45}$ I. KUŠAN et al., 2018, 15-47.

${ }^{46}$ I. KUŠAN et al., 2015, 51-63.

${ }^{47}$ M. GAJIĆ-ČAPKA, 2003.
} 
(3) Vrste vezane za stare šume i prašume pod utjecajem lokalno-specifičnih klimatskih karakteristika

Prašume danas nalazimo na vrlo malim i međusobno jako izoliranim površinama te kao takve predstavljaju vrlo rijedak tip šumskih staništa, najviše zbog neprekidnog korištenja prirodno potencijalnog šumskog prostora tijekom dugog povijesnog razdoblja $\mathrm{s}$ trendovima intenziviranja eksploatacije prirodnih resursa ${ }^{48}$. $\mathrm{U}$ prašumama je sastav vrsta spontan i u njima se odvijaju isključivo prirodni procesi bez direktnog utjecaja čovjeka. Jedna od najupadljivijih specifičnosti prašuma je proces rasta i umiranja stabala uslijed čega stalno nastaju novi krupni drvni ostaci (ležeća i stojeća debla te raspukli panjevi) koji nedostaju u gospodarenim šumama. Sukcesivno razlaganje tih krupnih drvnih ostataka odvija se zahvaljujući posebnoj grupi lignikolnih saprotrofnih, odnosno "prašumskih" gljiva ${ }^{49}$. Te gljive ne mogu živjeti u gospodarenim šumama zbog nedostatka kontinuirane dostupnosti dovoljnih količina krupnih drvnih ostataka i odlični su indikatorski organizmi za procjenjivanje kvalitete prašumskih staništa, na što je za regionalne prilike ukazala već Milica Tortić ${ }^{50}$. Njihov jedini životni prostor čine različiti tipovi prašuma zbog čega su danas sve prašumske gljive vrlo ugrožene.

\section{Velebitea chrysotexta I. Kušan, Matočec \& Jadan}

Nedavna istraživanja bioraznolikosti gljiva u subalpskim prašumama bukve NPSV-a (Hajdučki kukovi) rezultirala su pronalaskom nove gljivlje vrste i ujedno novog roda (utvrđena posebna filogenetska linija unutar porodice Lachnaceae) za znanost $^{51}(\mathrm{Sl}$. 4d, f). Osim na jednom lokalitetu u NPSV-u, $V$. chrysotexta je uskoro pronađena i u Nacionalnom parku Paklenica (prašuma u području Javornik) u istom tipu šume u sličnim ekološkim uvjetima. Ova vrsta svoje stanište pronalazi isključivo u subalpskoj zoni u šumama s bukvom. Živi kao razlagač protrulih krupnih ostataka bukve ukopanih u duboki listinac, u prašumskim staništima. Subalpske prašume bukve koje nalazimo u oba navedena područja nedavno su upisane na Popis svjetske baštine UNESCO-a. Mikološka podloga izrađena kao podrška u evaluaciji toga područja ${ }^{52}$, pokazala je utemeljenost argumenta za ovaj status koji su dodatno osnaženi rezultatima naknadnih istraživanja.

\footnotetext{
${ }^{48}$ F. M. SABATINI et al., 2018, 1426-1439.

${ }^{49}$ P. ÓDOR et al., 2006, 58-71; Z. TKALČEC et al., 2008, N. JUKIĆ et al. 2009.

${ }^{50}$ M. TORTIĆ, 1998, 139-146.

${ }^{51}$ R. PHOOKAMSAK et al., 2019, 1-273.

${ }^{52}$ N. MATOČEC - I. KUŠAN, 2016a.
} 

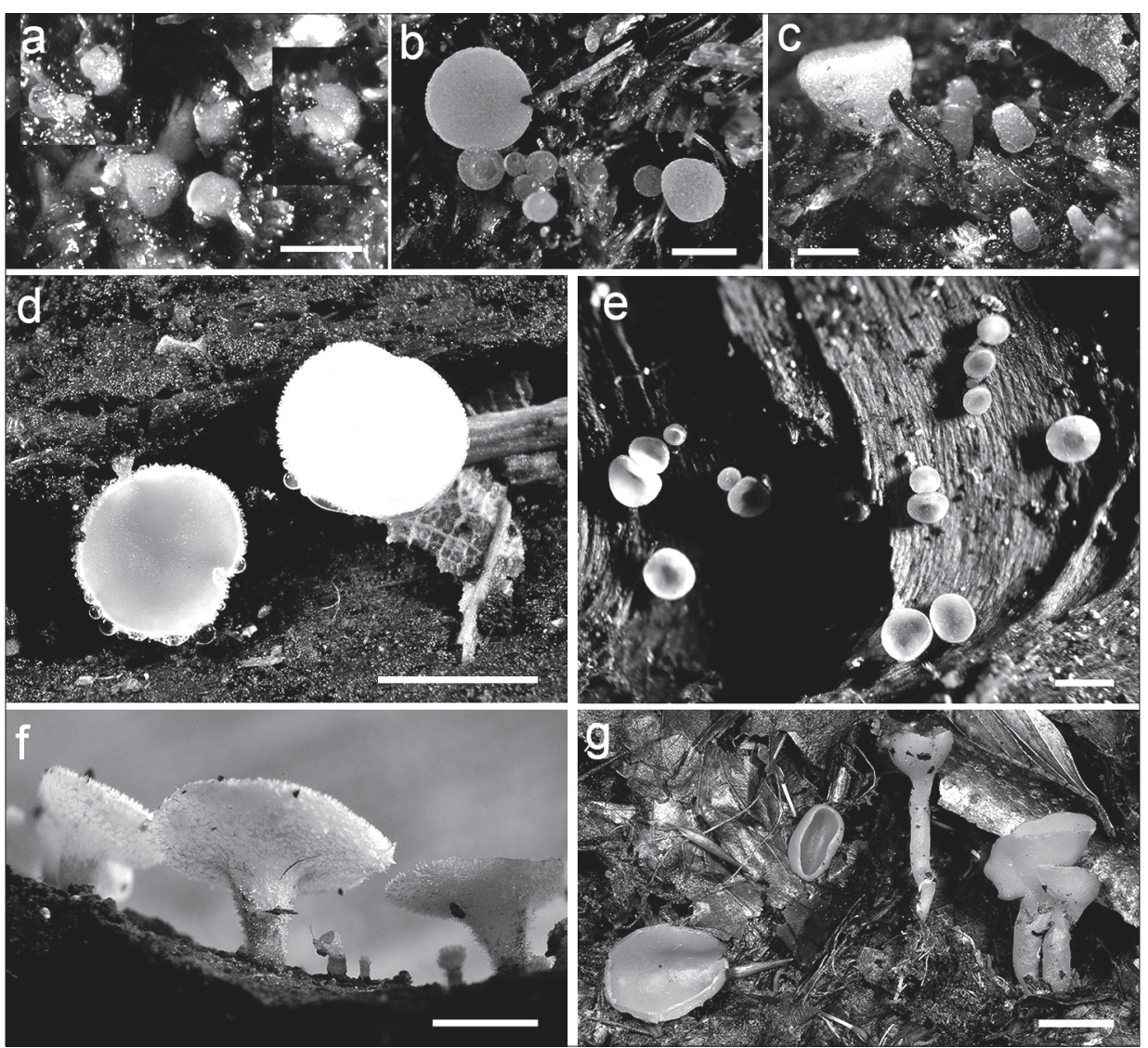

Sl. 4. Ekološki stenovalentne gljivlje vrste. a) Coprotus epithecioides, plodišta na izmetu divokoze; b) i c) Thecotheus platyapiculatus, b) plodišta na izmetu konja odozgora, c) plodišta bočno; d) Velebitea chrysotexta na trulim ostacima bukve - plodišta odozgora; e) Mollisia endocrystallina, plodišta na trupcu smreke; f) Velebitea chrysotexta - plodišta bočno; g) Sowerbyella fagicola, plodišta u listincu bukve. Mjerila: a-c $=0.5 \mathrm{~mm} ; \mathrm{d}=2 \mathrm{~mm}$; e-f $=1 \mathrm{~mm} ; \mathrm{g}=1 \mathrm{~cm}$. (Foto: N. Matočec i I. Kušan)

Mollisia endocrystallina Matočec, I. Kušan et al.

Intenzivna istraživanja gljiva iz odjeljka Ascomycota obuhvatila su i subalpske prašume smreke. Poseban fokus predstavljale su takve šume koje su se razvile pod temperaturnom inverzijom kao poseban oblik vegetacije mrazišta koja se razvija u pridnenim dijelovima zatvorenih depresija u kršu kao što su to ponikve, 
dolci, padeži i polja u kojima vladaju specifični uvjeti ${ }^{53}$. Na krupnim ostacima smreke pod snažnom zasjenom lokalnog reljefa i prašumskog svoda krošanja smreke, pri samom dnu duboke ponikve kojeg tijekom 2/3 ili 3/4 godine prekriva naslaga snijega, pronađena je $M$. endocrystallina (Sl. 4e) koja je do tada bila nepoznata znanosti ${ }^{54}$.

\section{Sowerbyella fagicola J. Moravec}

Ova iznimno rijetka vrsta (Sl. $4 \mathrm{~g}$ ) ne spada u tipične prašumske gljive jer ne razlaže krupne drvne ostatke, pa ni tanje grane. Čini se da je snažno vezana za viša planinska područja i debele akumulacije listinca bukve u kojima se tijekom duljeg vremena zadržava visoka razina vlažnosti, za što je prvi ključan čimbenik postojanje starije šumske sastojine ili prašume zatvorenog svoda krošanja. Pronađena je samo jednom u altimontanoj zoni s bukvom, pri čemu je zamijećeno da se čak ni i iznimno debele naslage listinca ne zadržavaju trajno na istoj mikro-lokaciji. S. fagicola je novozabilježena vrsta za mikobiotu Hrvatske.

\section{Zaključci}

$\mathrm{Na}$ temelju rezultata ovoga rada, definirano je nekoliko kategorija kao odraza specifičnosti stila života nekih gljivljih vrsta s prijedlogom primjene u domeni zaštite prirode. U slučaju kada su određene vrste živih organizama obligatno biotrofno vezane na drugu vrstu - domaćina koji je endem, uvodimo termin endemobioza koja istovremeno odražava indikaciju za zaštitu obje vrste (i domaćina i vrste koja je s njom biotrofno povezana) odnosno predstavlja specifični razlog (potencijalne ili aktualne) ugroženosti. Ovi odnosi utvrđeni su na primjerima navedenih endemobiontnih gljiva Pyrenopeziza velebitica i Rhachomyces hypogaeus, i njihove visoke razine specijaliziranosti na posebne domaćine. Također, može se predvidjeti i kategorija endemofilnost za organizme koji mogu živjeti samo u biotrofnoj vezi s nekolicinom međusobno srodnih različitih vrsta, ali su u najvećoj mjeri prisutni u vezi s onom (ili onima) endemičnom. Kod gljiva često nalazimo vrste koje su u ekološkom smislu obligatno ili tek fakultativno vezane za određeni tip staništa, određeni trofički modus ili određene druge vrste organizama ${ }^{55}$.

${ }^{53}$ N. MATOČEC et al., 2019.

${ }^{54}$ P. CROUS et al., 2019, 291-473.

${ }^{55}$ N. JUKIĆ et al. 2019; I. KUŠAN - N. MATOČEC, 2018; N. MATOČEC, 2002, 1-112; N. MATOČEC - I. KUŠAN, 2016b. 
Potencijalna endemičnost ili izrazita fragmentiranost malih populacija su podjednaki argumenti za zaštitu i mogu se $\mathrm{s}$ visokom razinom vjerojatnosti pretpostaviti kod nekolicine predstavljenih vrsta kod kojih postoji opća ekološka stenovalentnost. Te vrste vrlo su vjerojatno specijalizirane na pojedine tipove supstrata, na kojima se pojavljuju u teleomorfnoj fazi (jedinom obliku u ukupnoj pojavnosti gljiva u kojem dolazi do genetičke rekombinacije), pod specifičnim ekološkim uvjetima (Coprotus epithecioides, Mollisia endocrystallina, Sowerbyella fagicola, Thecotheus platyapiculatus i Velebitea chrystexta). Ti čimbenici dio su temeljne zaštite Nacionalnog parka Sjeverni Velebit, a nalazi ovih gljiva, kao i prethodno navedenih endemobiontnih, koje su do danas jedino poznate s prostora Parka ili čine jedine poznate nalaze na nacionalnoj razini, odražavaju njegovu izvrsnu prostornu te funkcionalnu osmišljenost.

Kod vrste $S$. fagicola utvrđena je prirodna nestabilnost mikrostanišnih / supstratnih uvjeta na promatranom području. Ova vrsta za svoj život traži lokalizirane duboke naslage listinca bukve u hladnom pojasu s obiljem oborina i dugotrajnim zadržavanjem vlage. Vrsta $S$. fagicola pripada svojevrsnim indikatorima vrlo osjetljivih mikrostaništa koji su definirani nedavnim istraživanjima u susjednoj Bosni i Hercegovini ${ }^{56}$, posebno u šumskim staništima na visokim planinama Dinarida gdje je snažan utjecaj vjetra i površinske erozije. Višekratnim obilaskom, ne samo nalazišta ove vrste, već i širokog područja sa sličnim stanišnim uvjetima, utvrđeno je da ovakve duboke naslage nisu stabilne (najvjerojatnije zbog izloženosti udarima bure) niti se uvijek u odgovarajuće godišnje doba u njima zadržava dovoljno vlage. Ako određeni tip mikrostaništa, ključan za život određene vrste nije fizički stabilan i nema osigurane sezonske ekofiziološke uvjete unutar okvira strogog režima zaštite (pasivna zaštita u Nacionalnom parku), a stabilnost se ne može osigurati niti aktivnim mjerama zaštite, otkriva se novi razlog ugroženosti koji također generira razlog za zaštitu i to na širokom (nacionalnom) planu. Stoga, vrstama iz ove skupine ugroženosti treba pridati posebnu pažnju i izvan okvira zaštićenih područja.

Navedene vrste, kao i brojne druge koje nisu ovdje obrađene, imaju indikatorske vrijednosti u smislu pokazatelja kvalitete staništa. One su ujedno su i pokazatelji stanišnih tipova vrlo visoke geospecifičnosti (npr. vegetacijski tipovi ili špilje bogate endemskom faunom) koji su rasprostranjeni na vrlo malim površinama s populacijama pojedinih vrsta koje su međusobno vrlo izolirane. U okviru 12 godina istraživanja gljiva iz odjeljka Ascomycota

${ }^{56}$ N. JUKIĆ et al., 2019. 




S1. 5. Slijepa karta NPSV-a s ucrtanim područjima posebne zaštite (Hajdučki i Rožanski kukovi te botanički rezervati Visibaba i Zavižan - Balinovac - Velika kosa). Plave točke označavaju mjesta nalaza strogo zaštićenih vrsta gljiva, a crvene mjesta nalaza vrlo rijetkih vrsta kandidata za strogu zaštitu. (Pripremio: D. Mrvoš) 
pronađeno je 10 ugroženih i strogo zaštićenih vrsta $^{57}, 37$ vrlo rijetkih vrsta smatramo kandidatima za strogu zaštitu ${ }^{58}$ (Sl. 5) a zabilježeno je ukupno 162 vrste s različitim tipovima bioindikatorskih atributa koje nisu nužno ni vrlo rijetke i/ili strogo zaštićene ${ }^{59}$. Indikatorski atributi su ovim dugotrajnim istraživanjem kalibrirani za lokalno područje i moguće je da u udaljenim prostorima drugih biogeografskih regija (s drugačijim podnebljem) iste vrste mogu imati drugačiju indikatorsku vrijednost.

Bez obzira na to, mnoge gljivlje vrste su iznimno kvalitetni i pouzdani pokazatelji posebnih tipova staništa i njihove kvalitete na europskom planu, posebno zbog toga što nam pojava njihovih plodišta u smislu visoke bioraznolikosti i produktivnosti signalizira vitalnost tih vrsta, a time ukazuje na vrlo povoljne prilike u okolišu i obrnuto, što je ranijom studijom provedenom u susjednoj regiji (Gorski kotar) utvrđeno u pogledu opterećenosti staništa zračnim onečišćenjem $^{60}$. Određeni dio tih vrsta, $\mathrm{s}$ makroskopski vidljivim plodištima, moguće je pouzdano karakterizirati (posebice u današnje vrijeme kada nam genetičke analize omogućavaju nepogrešiv alat za karakterizaciju) kako bi se one mogle pratiti na terenu uz pomoć ne-mikološkog, za tu svrhu educiranog kadra u sustavu zaštite prirode. Te bi vrste, posebno imajući u vidu presudnu ulogu koju gljive imaju u održanju kopnenih ekosustava, zasigurno bile od prvorazredne važnosti i za sustav zaštite NATURA 2000 koji do danas nije u svoje direktive uključio nijednu gljivlju vrstu ${ }^{61}$ ! Smatramo stoga, da bi uključivanje određenih gljivljih vrsta u direktive NATURA 2000 značajno unaprijedilo taj sustav i ono bi se trebalo konstruktivno shvatiti kao imperativ.

I danas, nakon 12 godina istraživanja odabranih skupina gljiva iz odjeljka Ascomycota, može se primijetiti da se broj novozabilježenih vrsta u svakom bloku terenskih istraživanja ne približava asimptoti, odnosno kako smo još daleko od približavanja poznavanju ukupne bioraznolikosti tih gljiva. U prikazanom 10-godišnjem rasponu s intenzivnim istraživanjem (2003, 2006, 2008-2014 i 201662), vidljiv je razmjerno ujednačen i značajan udio novozabilježenih vrsta za Park (uključujući i velik broj novozabilježenih vrsta za mikobiotu Hrvatske), proporcionalan ostvarenom naporu svakog

\footnotetext{
${ }^{57}$ Z. TKALČEC et al., 2008; I. KUŠAN et al., 2016.

${ }^{58}$ I. KUŠAN et al., 2017.

${ }^{59}$ N. JUKIĆ et al., 2019.

${ }^{60}$ N. MATOČEC et al., 2000, 15-33.

${ }^{61}$ SLUŽBENI LIST EUROPSKE UNIJE, SL L 206, 22. 7. 1992; SL L 158, 10. 6. 2013.

${ }^{62}$ I. KUŠAN et al., 2017.
} 
pojedinog bloka terenskog istraživanja (S1. 1), koji je (osim u 2003., prvoj godini intenzivnog istraživanja u kojoj su sve zabilježene vrste bile ujedno i novozabilježene za Park) varirao između $1 / 3$ i $2 / 3$. Nakon svake godine istraživanja zabilježeno je prosječno 28 novozabilježenih vrsta. Stoga je potrebno osigurati dugotrajno istraživanje bioraznolikosti gljiva na određenom području, ukoliko želimo spoznati veći dio postojeće mikobiote toga područja. Sličan, ali prostorno, organizacijski i taksonomski mnogo šire obuhvatniji program, koji je nizom projekata i intenzivnim terenskim istraživanjima tijekom deset godina obuhvatio različite skupine živih organizama Finske ${ }^{63}$, pokazao je da i borealno te subarktičko područje, koja se često smatraju biogeografskim područjima najniže razine bioraznolikosti te istovremeno vrlo visoke razine istraženosti, sadrže još uvijek vrlo visok udio nepoznate bioraznolikosti te mnoge nepoznate vrste za znanost. U odjeljku Ascomycota, tim je programom bilo zabilježeno 66 novih vrsta za područje Finske, dok su dvije vrste bile novoopisane, do tada nepoznate znanosti.

U okviru odjeljka Ascomycota, pet je vrsta (i jedan rod) bilo potpuno nepoznato znanosti do recentnog provođenja intenzivnih istraživanja. Ovakav je rezultat bio moguć samo na temelju osiguranog dugotrajnog istraživanja bioraznolikosti askomiceta, ali i detaljnog promatranja načina života određenog broja odabranih vrsta i ekoloških uvjeta koji vladaju u Parku. Iz svih gore navedenih rezultata istraživanja, izrasta i značaj ovog Parka u domeni fundamentalne ekologije (sinekologije). Također, zahvaljujući ovom Parku osigurano je i kvalitetno praćenje populacija drugih vrsta, ekoloških skupina vrsta te cijelih sinuzija i biocenoza u okviru prirodnih procesa, neometanih direktnim antropogenim utjecajima. Osim pasivnih oblika zaštite (osiguravanje dominacije prirodnih procesa), u Parku se provode i određene mjere aktivne zaštite kojima je prvenstveno cilj održavanje antropogenih travnjaka nastalih tradicionalnim, izrazito geospecifičnim, pokretnim (transhumantnim) stočarenjem. Ovakav veliki doprinos NPSV-a mikološkoj znanosti nije mogao proći bez pojave povratne sprege u kojoj su angažirani mikolozi, zahvaljujući ukupnoj organiziranosti Parka, dobili ključne informacije na temelju kojih je bilo moguće izraditi dio potpore za njegov daljnji razvoj ${ }^{64}$. Kao konačan zaključak može se navesti da se područje NPSV-a, prema svim ranije uspostavljenim kriterijima ${ }^{65}$ može

${ }^{63}$ A. JUSLÉN - S. SIRKIÄ, 2013, 811-823.

${ }^{64}$ I. KUŠAN et al., 2016; N. MATOČEC - I. KUŠAN, 2016a; I. KUŠAN - N. MATOČEC, 2018.

${ }^{65}$ S. EVANS et al., 2001; N. JUKIĆ et al., 2019. 
označiti kao Područje važno za gljive - Important Fungus Area (IFA) iznimne složenosti staništa i visoke bioraznolikosti gljiva, što predstavlja i nadopunu ranije provedene studije za područje Hrvatske ${ }^{66}$.

\section{Zahvala}

Autori zahvaljuju Javnoj ustanovi Nacionalni park Sjeverni Velebit na višegodišnjem financiranju mikoloških istraživanja na području Parka. Speleologu Predragu Radeu zahvaljuju na sakupljanju entomološkog materijala, a Romanu Ozimecu na izolaciji jedinki kukaca s gljivom Rhachomyces hypogaeus.

\section{Literatura}

Jean BALAZUC, Fungi parasiti, Laboulbenia, u: Christian JUBERTHIE - Vasile DECU (ur.), Encyclopaedia Biospeologica, Tome II, Société de Biospéologie, Moulis Bucarest, 1998, 1305-1309.

Hans-Otto BARAL - Ricardo GALÁN-MARQUEZ - Irmgard KRISAI-GREILHUBER - Neven MATOČEC - James Terence PALMER, Tatraea dumbirensis, new records of a rare leotialean discomycete in Europe, Osterreichische Zeitschrift fur Pilzkunde, 8, 1999, 71-82.

Steen N. CHRISTENSEN, Contribution to the lichen flora of Jugoslavia, Acta Botanica Croatica, 46, 1987,161-171.

Steen N. CHRISTENSEN - Eric Steen HANSEN, Lichens of Croatia, Acta Botanica Croatica, 53, 1994, 101-113.

Pedro W. CROUS - Mike J. WINGFIELD - Treena I. BURGESS - Angus J. CARNEGIE - Giles E. St. J. HARDY - David SMITH - Brett A. SUMMERELL - José F. CANO-LIRA - Josep GUARRO - Jos HOUBRAKEN, et al., Fungal Planet description sheets: 625-715, Persoonia, 39, 2017, 270-467.

Pedro W. CROUS - Angus J. CARNEGIE - Mike J. WINGFIELD - R. SHARMA - Giovanni MUGHINI - Machiel E. NOORDELOOS - Alberto SANTINI Yogesh S. SHOUCHE - Jadson D. P. BEZERRA - Bálint DIMA, et al., Fungal Planet description sheets: 868-950, Persoonia, 42, 2019, 291-473.

Árpád von DEGEN, Lichenes, u: Árpád DEGEN (ur.), Flora Velebitica. III. - Ungar, Akademie der Wissenschaften, Budapest, 1938, 299-379.

William R. ELLIOTT, Conservation of the North American cave and karst biota, u: H. WILKENS - D.C. CULVER - W.F. HUMPHEYS (ur.), Ecosystems of the World, $30,2000,665-689$.

${ }^{66}$ Z. TKALČEC et al., 2005 b. 
Shelley EVANS - Peter MARREN - Martin HARPER, Important Fungus Areas: a provisional assessment of the best sites for fungi in the United Kingdom, Plantlife International, Salisbury, 2001.

Brian W. FERRY - M. Susan BADDELEY - David Leslie HAWKSWORTH, Air Pollution and Lichens, Athlone Press, London, 1973.

Marjan GAJIĆ-ČAPKA (ur.), Zavižan između snijega, vjetra i sunca, DHMZ - HMD, Zagreb, 2003.

David Leslie HAWKSWORTH, The fungal dimension of biodiversity: magnitude, significance, and conservation, Mycological Research, 95(6), 1991, 641-655.

Larry HULDÉN, Laboulbeniales (Ascomycetes) of Finland and adjacent parts of the U.S.S.R, Karstenia, 23(2), 1983, 31-136.

JUNP Sjeverni Velebit, Ekološka mreža NATURA 2000 u Nacionalnom parku Sjeverni Velebit, JU "Nacionalni park Sjeverni Velebit", Krasno, 2017.

Nedim JUKIĆ - Neven MATOČEC - Ivana KUŠAN - Rade GAŠIĆ - Nihad OMEROVIĆ - Smiljan TOMIĆ, Diversity of Ascomycetous Fungi in the Territories of Protected Areas and in the Areas Evaluated for the Protection in Bosnia-Herzegovina Establishing Important Fungus Areas (IFA), Mycological Society MycoBH, Sarajevo, 2019.

Aino JUSLÉN - Saija SIRKIÄ, The unknown northern green: evaluation of a national forest biodiversity research program, Biodiversity Conservation, 22, 2013, 811823.

Fran KUŠAN, Prodromus lišaja Jugoslavije, JAZU, Zagreb, 1953.

Ivana KUŠAN - Neven MATOČEC, Program monitoringa gljiva travnjaka Nacionalnog parka Sjeverni Velebit u sklopu Projekta uvođenja ispaše na travnjak Lubenovac Nacionalnog parka Sjeverni Velebit (elaborat), 2018.

Ivana KUŠAN - Neven MATOČEC - Dušan MRVOŠ, Ten years of research on Ascomycota (Fungi) in the Sjeverni Velebit National Park (Znanstveno-stručni skup "Od istraživanja ka dobrom upravljanju Nacionalnim parkom Sjeverni Velebit", zbornik sažetaka), JU NP "Sjeverni Velebit", Krasno, 44-45, 2017.

Ivana KUŠAN - Neven MATOČEC - Armin MEŠIĆ - Roman OZIMEC - Zdenko TKALČEC, Centar za posjetitelje Krasno. Izrada detaljnih stručnih elaborata uređenja postava. Grupa V. - Gljive (elaborat), JU Nacionalni Park Sjeverni Velebit, Krasno, 2016.

Ivana KUŠAN - Neven MATOČEC - Armin MEŠIĆ - Zdenko TKALČEC, A new species of Thecotheus from Croatia with a key to the known species with apiculate spores, Sydowia, 67, 2015, 51-63.

Ivana KUŠAN - Neven MATOČEC - Margita JADAN - Zdenko TKALČEC - Armin MEŠIĆ, An overview of the genus Coprotus (Pezizales, Ascomycota) with notes on the type species and description of C. epithecioides sp. nov., Mycokeys, 29, 2018, 15-47. 
Adolf H. MAGNUSSON, A Monograph of the Lichen Genus Jonaspis, Acta Horti Gothoburgensis, 8, 1933, 1-47.

Neven MATOČEC, The endangered European species Poronia punctata (Xylariales, Ascomycotina) still alive and well in Croatia, Natura Croatica, 9(1), 2000, 35-40.

Neven MATOČEC, Cave Fungi, u: Sanja GOTTSTEIN MATOČEC (ur.), An Overview of Cave and Interstitial Biota of Croatia, Natura Croatica, 11(Suppl. 1), 2002, 21-27.

Neven MATOČEC - Oleg ANTONIĆ - Dušan MRVOŠ - Andrej PILTAVER Dalibor HATIĆ - Dragan BUKOVEC, An estimate of fir forest health based on mycobioindication: the Križ stream catchment area, Gorski kotar, Croatia, a case study, Natura Croatica, 9(1), 2000, 15-33.

Neven MATOČEC - Nedim JUKIĆ - Nihad OMEROVIĆ - Ivana KUŠAN, Dinaric karst poljes and their importance for mycobiota, u: Peter SACKL - Stefan FERGER - Nermina SARAJLIĆ - Dražen KOTROŠAN - Goran TOPIĆ, Dinaric Karst Poljes - Nature conservation and rural development, Ornitološko društvo "Naše Ptice", Sarajevo, 2019.

Neven MATOČEC - Ivana KUŠAN, Mycological evaluation of virgin beech forest of Strict reserve "Hajdučki i Rožanski kukovi" - An evaluation for the project: Nomination dossier to the UNESCO for the inscription on the World Heritage List (elaborat), 2016a.

Neven MATOČEC - Ivana KUŠAN, Gljive (Mikobiota), u: Roman OZIMEC (ur.), Đurđevečki peski, 40-43, 2016b, ADIPA, Zagreb.

Neven MATOČEC - Ivana KUŠAN - Roman OZIMEC, The genus Polycephalomyces (Hypocreales) in the frame of monitoring Veternica cave (Croatia) with a new segregate genus Perennicordyceps. Ascomycete.org, 6(5), 2014, 125-133.

Neven MATOČEC - Ivana KUŠAN - Roman OZIMEC, First record of cave fungus Rhachomyces hypogaeus (Ascomycota) in Sjeverni Velebit National Park (Znanstveno-stručni skup "Od istraživanja ka dobrom upravljanju Nacionalnim parkom Sjeverni Velebit", zbornik sažetaka), JUNP "Sjeverni Velebit" Krasno, 2017.

Tihomir MILIČEVIĆ - Joško KALITERNA - Dario IVIĆ - Milenko MILOVIĆ, Records of phytopathogenic fungal species on native plants new to Croatia, Natura Croatica, 23(1), 2014, 179-187.

Gusztáv MOESZ, Fungi, Aufzählung der im Velebit-Gebirge bisher beobachteten Pilzen, u: Árpád DEGEN (ur.), Flora Velebitica. III. - Ungar, Akademie der Wissenschaften, Budapest, 1938, 281-298.

Peter ÓDOR - Jacob HEILMANN-CLAUSEN - Morten CHRISTENSEN - Erik AUDE - Klaus W. VAN DORT - Andrej PILTAVER - Iren SILLER - Mirjam T. VEERKAMP - Ruben WALLEYN - Tibor STANDOVÁR - Ad F. M. VAN HEES - Jože KOSEC - Neven MATOČEC - Hojka KRAIGHER - Tine GREBENC, Diversity of dead wood inhabiting fungi and bryophytes in semi-natural beech forests in Europe, Biological Conservation, 131(1), 2006, 58-71. 
Roman OZIMEC - Lana BARIČEVIĆ - Neven MATOČEC - Ivana KUŠAN - Armin MEŠIĆ - Zdenko TKALČEC, Fimicolous organisms, indicators of biodiversity \& grassland habitats: Example from Natural Park Biokovo Mt., u: Vladimir PEŠIĆ (ur.), The Book of Abstracts and Programme - V. International Symposium of Ecologists of Montenegro, Podgorica, Book of abstract, 2013.

RungtiwaPHOOKAMSAK-KevinD.HYDE-Rajesh JEEWON-Darbhe JayaramaBHAT

- Evan B. Gareth JONES - Sajeewa S. N. MAHARACHCHIKUMBURA - Olivier RASPÉ - Samantha C. KARUNARATHNA - Dhanushka N. WANASINGHE - Sinang HONGSANAN, et. al., Fungal diversity notes 9291035: taxonomic and phylogenetic contributions on genera and species of fungi, Fungal Diversity, 95, 2019, 1-273.

Jasenka RADOVIĆ (ur.), Ekološka mreža na području Velebita, Državni zavod za zaštitu prirode, Zagreb, 2007.

Francesco Maria SABATINI - Sabina BURRASCANO - William S. KEETON-Christian LEVERS - Marcus LINDNER - Florian PÖTZSCHNER - Pieter Johannes VERKERK - Jürgen BAUHUS - Erik BUCHWALD - Oleh CHASKOVSKY, et al., Where are Europe's last primary forests?, Diversity and Distributions, 24, 2018, 1426-1439.

Sergi SANTAMARIA - Arnaud FAILLE, Rhachomyces (Ascomycota, Laboulbeniales) parasites on cave-inhabiting Carabid beetles from the Pyrenees, Nova Hedwigia, 85(1-2), 2007,159-186.

Miroslav SERVÍT, Flechten aus Jugoslavien, Hedwigia, 69, 1929,1-38.

Miroslav SERVÍT, Flechten aus Jugoslavien, Hedwigia, 71, 1931, 215-282.

Miroslav SERVÍT, Flechten aus Jugoslavien, Hedwigia, 74, 1934,119-160.

Miroslav SERVÍT, Lichenum sectionis Verrucaria sphinctrina revisio critica, Beihefte zum Botanischen Centralblatt 59 B, 1939, 113-168.

Vladimir ŠKORIĆ, Mikološki prilog flori Hrvatske i Slavonije s osobitim obzirom na parasitske gljive, Glasnik Hrvatskoga prirodoslovnoga društva, 39/40, 1928, 97-108.

Zdenko TKALČEC - Armin MEŠIĆ - Oleg ANTONIĆ, Agaricales (Basidiomycota, Fungi) of Sjeverni Velebit National Park in Croatia, Periodicum Biologorum, 107(3), 2005a, 341-349.

Zdenko TKALČEC - Armin MEŠIĆ - Neven MATOČEC, Područja važna za gljive kao dio nacionalne ekološke mreže (elaborat), $2005 \mathrm{~b}$.

Zdenko TKALČEC - Armin MEŠIĆ - Neven MATOČEC - Ivana KUŠAN, Crvena knjiga gljiva Hrvatske, Državni zavod za zaštitu prirode i Ministarstvo kulture, Zagreb, 2008.

Milica TORTIĆ, New records for Yugoslavia of some resupinate polypores, Acta Botanica Croatica, 39, 1980a, 145-151.

Milica TORTIĆ, Studies in the Corticiaceae (Mycophyta, Basidiomycetes) of Yugoslavia I, Biosistematika 6, 1980b, 15-25. 
Milica TORTIĆ, Macromycetes in mountain Velebit (Croatia), Acta Botanica Croatica, 52, 1993, 81-96.

Milica TORTIĆ, An attempt to a list of indicator fungi (Aphyllophorales) for old forests of beech and fir in former Yugoslavia, Folia Cryptog. Estonica, 33, 1998, 139146.

\section{Internetski izvori}

SLUŽBENI LIST EUROPSKE UNIJE, 1992, Direktiva 92/43/EEZ o zaštiti prirodnih staništa i divljih biljnih i životinjskih vrsta (SL L 206, 22. 7. 1992.), URL: https:// eur-lex.europa.eu/legal-content/HR/TXT/PDF/?uri=CELEX:31992L0043\&from $=\mathrm{EN}(2019-11-04)$

SLUŽBENI LIST EUROPSKE UNIJE, 2013, Direktiva Vijeća 2013/17/EU o prilagodbi određenih direktiva u području okoliša zbog pristupanja Republike Hrvatske (SL L 158, 10. 6. 2013.), URL: https://eur-lex.europa.eu/legal-content/HR/TXT/PDF /?uri=CELEX:32013L0017\&from=EN (2019-11-04)

NACIONALNI PARK SJEVERNI VELEBIT, URL: http://www.np-sjeverni-velebit.hr/ park (2019-08-25)

NARODNE NOVINE, 2013, Uredba o ekološkoj mreži (NN 124/13), URL: https:// narodne-novine.nn.hr/clanci/sluzbeni/2013_10_124_2664.html (2019-11-04)

NARODNE NOVINE, 2013, Pravilnik o strogo zaštićenim vrstama (NN 144/13), URL: https://narodne-novine.nn.hr/clanci/sluzbeni/2013_12_144_3086.html (2019-11-04)

\section{THE SIGNIFICANCE OF THE NORTHERN VELEBIT NATIONAL PARK IN THE PROTECTION OF NATURE REGARDING FUNGI}

\section{Summary}

The region of Northern Velebit National Park is characterised by a high diversity of fungi. Around 750 species have been recorded to date, of which 20 are strictly protected while 37 are very rare on the global scale and currently without conservation status in Croatia. Latest intensive mycological research has resulted in the publication of one genus and as many as five species new to science. In this paper are discussed fungal species of high bioindicator values for the quality of the system of nature protection, presented in three groups: biotrophic species linked to endemic species - endemobionts, (2) ecologically stenovalent species linked to the faeces of animals and (3) ecologically stenovalent species linked to old forests and primeval forests. All three groups are under the strong influence of locally specific climatic characteristics. According to the analysed data, it can be said that the Northern Velebit National Park has been successfully designed with regard to the protection of fungi. Due to its diversity and specificity, the Northern Velebit National Park can be designated as an Important Fungus Area (IFA).

Keywords: endemobiont, endemophilous species, fungal ecology, IFA, protection of fungi 